\title{
Value Creation Concept In Stakeholder and Shareholder Economies
}

\author{
Zoran Mastilo ${ }^{1}$, Vladimir Zakić ${ }^{2}$, Goran Popović ${ }^{3}$ \\ ${ }^{1}$ University of East Sarajevo - Faculty of business economy, Semberskih ratara bb, 76300 Bijelijna, Bosnia and \\ Herzegovina. \\ ${ }^{2}$ University of Belgrade - Faculty of Agriculture, Nemanjina Street no. 6, 11080 Zemun-Belgrade, Serbia \\ ${ }^{3}$ University of Banja Luka - Faculty of Economics, Majke Jugovica no. 4, 78000 Banja Luka, Bosnia and Herzegovina. \\ Correspondence: Zoran Mastilo, Ph.D., Associate Prefessor, University of East Sarajevo - Faculty of business economy, \\ Semberskih ratara bb, 76300, Bijelijna, Bosnia and Herzegovina.
}

\author{
Received: November 30, $2016 \quad$ Accepted: February 3, $2017 \quad$ Available online: February 6, 2017 \\ doi:10.11114/aef.v4i2.2200 URL: http://dx.doi.org/10.11114/aef.v4i2.2200
}

\begin{abstract}
In the financial theory it is common to make distinction between two types of corporate value creation concept: shareholder value and stakeholder value. In shareholder systems, also known as Anglo-American concept, institutional investors, who usually own small percentages of companies' shares, exert significant influence over managers. In major stakeholder systems, marked as Continental concept, influence is shared between large shareholders, employees, customers and suppliers. The aim of this paper is to analyze influence of globalization processes and economic crises on value creation theory and practice.
\end{abstract}

Keywords: stakeholders, value creation, value distribution

\section{Introduction}

Contemporary corporate business involved numerous groups of stakeholders. In addition to the owners, they include creditors, employees, consumers, suppliers, government agencies, etc. However, there are three key stakeholder groups which the corporation usually seeks to generate value: shareholders, customers and employees.

Looking at the historical development of the corporate enterprise, it can be concluded that in the 19th century and much of the 20th century the owners were the dominant stakeholders. Separation of the ownership and management in large corporations, which began in the United States and Great Britain even during the 19th century, caused the need for the emergence of the concept of shareholder value creation. Shareholders have always been interested in increasing their wealth, and managers publicly accepted that goal. As a basic and most important business goal stood out creating shareholder value through the constant growth of share prices and payment of dividends.

During the 1980s, however, significant change at the global level have occurred, such as the deregulation of capital markets, the development of information technology, development and increasing liquidity of the securities market, expansion of institutional and individual investors, etc. Also, the value of corporations is increasingly beginning to be based on intangible assets: brand, patents, quality, highly skilled employees etc. This led to the creation of many different influential groups, which significantly complicates the determination of the most important objective of the business.

The subject of this paper is a comparative analysis of shareholder value and stakeholder value concept, but also to discuss the problem of defining the concept of "value" that companies should generate.

\section{Characteristics and Objectives of Contemporary Corporations}

The first corporate enterprises, with the provision of limited liability, appeared in the 19th century in the UK. During the first decade of the 20th century in the United States there has been a drastic increase in the number of shareholders (from 500,000 in 1900 to over 10 million in 1930). Also, since 1920 there has been a large increase in the share prices. Economists of that period warned the public to be aware of overvalued shares and unrealistic expectations. A particular growth of stock prices was realized by companies in the field of new technologies for 1920's, such as the airline industry and the film industry.

March 1928 marks the beginning of speculative mania, when the "wannabe" shareholders started to invest their entire 
savings. In September 1929, the 240 most important companies on the New York Stock Exchange lost 2.8 billion dollars in market value [Frankfurter et al. 2003: 31-34].

Cyclical trends in the stock exchange prices, with occasional drastic disorders, were also present in the last decades of the 20th century and beginning of the 21st century. After the great financial "crash" on the New York Stock Exchange in October 1987 (the Black Monday), in the coming years came a period of great economic growth. However, by the late 20th century and early 21 st century there has been a downturn at the global level and a significant drop in the share prices of high technology companies. This short review of the historical cyclical trends point to the fact that the economic crisis of relatively lower intensity occur almost every decade, with occasional occurrence of extreme global crisis, which became apparent in 2008.

Using the term "corporation" usually indicates a modern corporate enterprises which forms its capital by issuing and selling shares. In some European countries the term modern corporation may include limited liability companies, such as Germany (Gesellschaft mit beschränkter Haftung - GmbH) and Italy (Società a responsabilità limitata - S.r.l). In the UK, the term corporation is often associated with the few remaining public enterprises, such as the BBC (The British Broadcasting Corporation). The practice of developed countries, despite the different terminology, recognizes two basic forms of corporate enterprises: private and public corporate enterprises.

Private corporations have a relatively small number of shareholders. They usually have full control and directly manage the company. These companies are known as "closed", since their shares are not quoted on the stock exchange market. It is common that the sale or purchase of shares of these companies is carried out exclusively with the consent and permission of the shareholders. These companies are mostly small or medium-sized.

Public corporations have a large number of shareholders, which can often be in tens or even hundreds of thousands. Their main strength is found in the number of owners, because in that way they can form a large equity. In the ownership structure of public corporations exist different categories of shareholders: large shareholders, institutional investors, government and small shareholders.

Due to the large number of shareholders, and the wide dispersion of ownership, public corporations implement separation of ownership and management function. Despite the fact that shareholders are not entitled to the direct disposal of invested funds, or have the right of their withdrawal from the business except in the case of liquidation of a company, they are formally and legally labeled as co-owners of the company. In the modern corporate enterprises, however, the majority of shareholders should essentially be called investors (in some cases even gamblers), which invest money only for profit, but not due to the realization of other property rights. A large number of small shareholders does not exercise its right to vote at shareholder meetings.

The objectives of a company is largely determined in accordance with the interests and power of the major stakeholders. Traditionally, main long-term goals of corporation is shareholder value creation and profit maximization. This understanding dates from the 19th century, in the period of the first occurrence of corporations, where the owners usually directly managed or participated in the management of the company. Those main goals can be achieved in several ways, such as minimizing cost, profitable investments, entering new markets, etc.

Long-term orientation towards shareholder value creation remains today one of the primary objectives, which can not be achieved without satisfying the interests of other key stakeholders. Contemporary business conditions increasingly necessitate that corporations take into account the interests of consumers. Also, there is a significant change in the relationship between the owners and employees whose knowledge and skills are particularly appreciated. As specific examples may be mentioned managers, professional athletes (in the UK for example football clubs operate in the form of joint stock companies), actors, bankers, engineers, etc., who earn very high income compared to total corporate revenue.

Stakeholder theory has infiltrated the academic dialogue in corporate management and a wide array of disciplines such as health care, law, and public policy. However, in spite of its importance to stakeholder theory, little attention has been devoted to questions regarding what it means to create value for stakeholders and how we can measure it. [Harrison, Wicks 2013: 97]

Regarding the financial aspect, we can maximize the accounting profit or cash flow. The concept of shareholder value creation is based on the thesis that the value for the owners is created by investments that generate a higher rate of return than the cost of capital, or investments that generate positive discounted cash flows [Rappaport, 2008: 2]. According to a similar view, the shareholders' wealth increases only if they earn higher returns (capital gains and dividends) compared with alternative investments of identical risk. However, that assessment in practice can be very subjective. The problem of measuring the shareholder wealth increase could be best explained by a hypothetical survey that could be carried out among the shareholders of a company - to the question "What amount of return you expect or want", the vast majority would surely reply "highest possible". 
Unlike shareholders, who are primarily oriented toward increasing their wealth, value creation measurement for other stakeholders may be accompanied by greater difficulties. For example, value creation for employees is not just a question of salaries. The basic characteristics of modern incentive system, both for managers and for other employees, may be expressed by philosophical notion that "money is not everything." In terms of relative poverty (which is predominantly present in developing countries, but to a significant extent also in developed countries), when people are fighting for their own survival and the survival of their families, the money is an absolute motivator. By achieving a certain level of living standards, which provides more than a "mere survival", employees begin to exclude money as the main and only motivator. In that situation, qualitative components of the incentive system are becoming more and more important. A large number of successful corporations in developed countries emphasize that one of their main goals is to provide interesting or fun place to work. Assessment of the consumers or customer value creation is even more of subjective character and may include: price/quality ratio (or exclusively quality in some cases), consumer perception of the product or service, etc.

The previous considerations point to the complexity of the goals expressed in contemporary corporations, from the aspect of the need to create a value. Starting from the practice of most developed countries, however, two main concepts of value creation could be separated: shareholder value creation and stakeholder value creation.

\section{Anglo-American Concept of Shareholder Value Creation}

In most Anglo-American countries, such as the United States and Great Britain, there is a wide dispersion of corporate ownership in public companies. The traditional system of shareholder value creation (Scheme 1) is characterized by the concentration of power in the hands of shareholders and managers, while other groups of stakeholders have a negligible impact. The structure of shareholders is consisted predominantly by large number of institutional investors (investment and pension funds, insurance companies, etc.) and small shareholders. Institutional investors usually do not invest in more than a few percentage of the shares of individual companies. As a result, the most significant conflicts or agency problems may occur in the relations , powerful managers - small shareholders ".

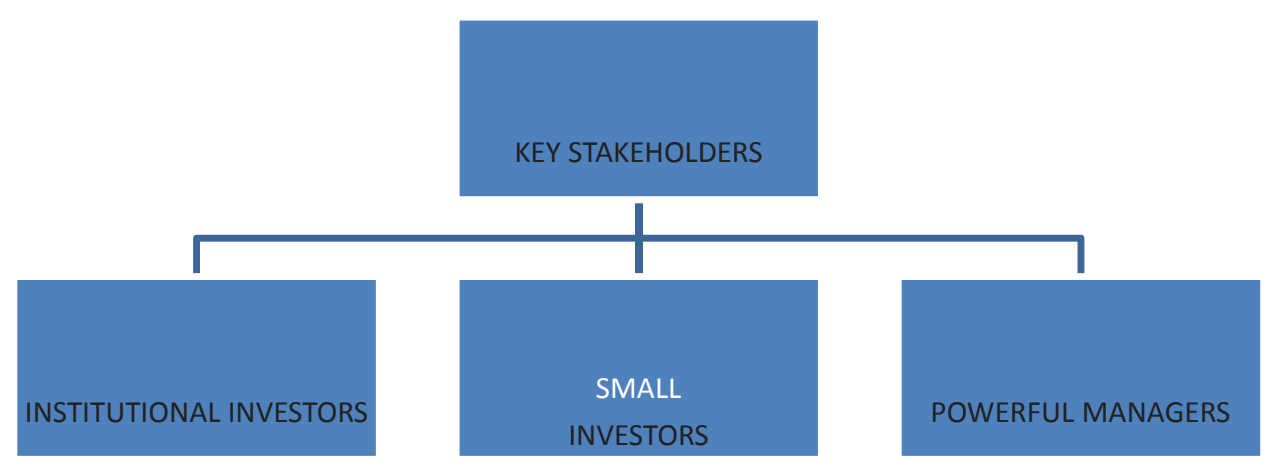

Figure 1. Key stakeholders in the traditional Anglo-American concept of shareholder value creation

According to Anglo American concept of business performance assessment, the most important goal is to create value for shareholders by maximizing market price of shares and payment of dividends. There are several ways how managers can affect the market price of the shares. The long-term growth in the share price could be achieved by profitable investments, corporate restructuring and so on. In practice, however, managers often are not interested in a long-term business profitability. Traditionally, the system of remuneration and evaluation of the work of managers is largely based on short-term results. If we take into account the fact that top managers often do "not survive" for more than a few years (quit or get fired), then their lack of interest in the long-term results becomes clear.

In short term, share prices may be boosted by increasing the periodic profit or cash flows through delays or reductions in investments and expenditures. Also, a short-term increase of the share price could be achieved by takeovers or mergers.

The price of shares in the short term can be boosted by publishing unreliable or even false information. At the beginning of the 21 st century, the professional community around the world has been shocked by scandal in multinational corporations, such as Enron. In order to fraud shareholders, this well-known corporation have falsified accounting and other significant business reports for several years.

Obviously, the exclusive focus on short-term results can benefit some shareholders or top managers, but at the expense 
of other stakeholders. The long-term consequences of such business policy are usually loss of business reputation, layoffs or staff turnover, a drop in sales and profits, as well as reducing the market value of the company. In the United States often is quoted statement of former President Abraham Lincoln: "You can fool all the people some of the time, and some of the people all the time, but you cannot fool all the people all the time." It can be concluded that a company that wants to provide business continuity, as well as the growth and development, must be oriented towards creating long-term value for all key stakeholders.

This view is increasingly being accepted in the United States, where the primary goal of shareholder value creation is associated with minimizing the social costs (eg. the devastation of the environment, significant layoffs, the use of non-renewable energy sources, etc.). American corporations are now trying to achieve image of „good citizen", who cares about its employees and the preservation of the environment, which certainly was not their top priority in the 20 century. Many corporations send the message to consumers that purchase of their products help preserve the environment (ecological packaging or production technologies), promote animal rights (products are not tested on animals) or improves the lives of people in developing countries (there is no labor exploitation, especially of children). In other words, it is increasingly recognized that the process of long-term value creation for shareholders is unattainable without social and environmental responsibility, taking into account the interests of employees and other key stakeholders.

\section{Continental Concept of Stakeholder Value Creation}

The main characteristic of the Continental concept is coopeation and creation of long-term relationships among the stakeholders. Term "Continental concept" combines the widely accepted theoretical understanding and practice of value creation outside the Anglo-American countries. The term is derived on the basis of the two most important groups of legal systems: the Anglo-Saxon and continental European system. ${ }^{1}$

Corporations that apply Continental concept traditionally take more care of the interests of other key stakeholders. Shareholder value creation in this model is also an essential goal, but for decades the owners accept the view that their long-term interests can not be satisfied unless they take into account the interests of other important groups of stakeholders. In addition to the most developed countries of continental Europe (Germany, France, Italy, etc.), in Japan is also dominantly accepted perceptions of the Continental concept of value creation.

As already discussed, there are considerable doubts about the general concept of value that can be interpreted and evaluated in different ways. The key difference in the understanding of the Anglo-American and Continental concept, relates to the interpretation of return expected by owners. In Anglo-American countries, characterized by the widespread dispersion of ownership, the majority of shareholders are primarily interested in the share price growth and dividend payments. On the other hand, in other developed countries there is a pronounced concentration of ownership. The majority shareholders have full control over the corporations and can efficiently control managers, thus largely avoiding agency problems in their relations. In the continental version of shareholder value creation, the basic criterions of operating performance are profit and cash flow. In other words, the value for the shareholder is generated if the company achieves profit that is higher than the profit of comparable companies. At the beginning of this century, member of the board of a major Japanese company asked an economist with a U.S. investment bank: ,Why should I care about my share price?" [Foudy 2003: 10]. This question clearly illustrates the difference in perception of shareholder value creation.

When analyzing the Continental concept of value creation, it is necessary to explain the conditions of the emergence of very substantial differences relating to the ownership structure of corporate enterprises and the development of financial markets. Unlike the USA, which is characterized by wide dispersion of ownership, developed countries of continental Europe and Japan are characterised by large concentration of ownership.

Compared with the US and the Great Britain, continental Europe is mostly characterized by concentrated ownership structure (Table 1). There are some perceptions that the differences in the dispersion of ownership occur as a result of different legal systems. The United States and Great Britain belong to the common law legal system, for which there is an opinion that it provides the best legal protection of investors. It is considered that is one of the reasons why these countries have the most developed financial markets. France and Italy belong to the subgroup of the French tradition of civil law, which provides a relatively low level of legal protection for shareholders. Germany and Japan could be classified as a subgroup of the Germanic tradition of civil law, which gives investors the level of protection between the common law and subgroups with the French civil tradition. [Jovanović 2002: 39]

\footnotetext{
${ }^{1}$ Without taking into account the traditional Sharia law.
} 
Table 1. Median Size of Largest Shareholding Block, mid-1990s [Sigurt 2003: 4]

\begin{tabular}{ll}
\hline \multicolumn{1}{c}{ Country } & $\begin{array}{l}\text { Largest voting block: } \\
\text { Median (\%) }\end{array}$ \\
\hline Germany & 57.0 \\
Belgium & 56.0 \\
Italy & 54.5 \\
Austria & 52.0 \\
Netherlands & 43.5 \\
Sweden & 34.9 \\
Spain & 34.5 \\
France (CAC 40) & 20.0 \\
UK & 9.9 \\
US - NYSE & 5.4 \\
$\quad$ NASDAQ & 8.6 \\
\hline
\end{tabular}

Weaknesses in the legal protection of investors in the European continental law system can be partially compensated by reducing the information asymmetry due to the ownership concentration.

As a result of different ownership structure, analysis of the value creation system is significantly different in the Continental concept. The major objective of the corporations in the traditional Anglo-American system represents maximization of shareholder wealth in accordance with the understanding that the shareholders are the primary stakeholders. In contrast, the Continental concept is characterized by a growing number of strategic objectives, such as sales growth or employees satisfaction. The most important characteristics of the continental concept can be explained through the two most representative countries: Japan and Germany.

Japan, like most East Asian countries, is characterized by strong concentration of ownership. Business groups keiretsu with a pyramidal and cross-over structures make the usual management structure. The term "keiretsu" refers to the large business group in Japan that are characterized by both horizontal and vertical integration. The most important keiretsu groups typically include a large bank, which is a reliable source of funding.

As an example, there is Mitsubishi keiretsu, that includes (or has included in a given period) several different activities: automotive, bank, chemical industry, etc. Close ties between managers and investors in Japanese companies significantly reduce information asymmetry and agency conflicts in relation to companies from the United States.

Germany is characterized by a very strong concentration of ownership. Unlike the US, German and Japanese banks have the possibility to hold a large percentage of industrial corporations shares in its ownership. Also, unlike the United States and Great Britain, small shareholders often buy shares through banks and they delegate their ownership voting right. As a result, banks have the possibility to control up to 90 percent of the votes at the general meeting of shareholders. In addition to banks, a significant percentage of ownership and management rights of some of the most famous German corporation are in the hands of the founding families ( BMW, Siemens, Krupp) and the state ( BMW, Preussag). [Sigurt 2003: 5]

Employees are another key group of stakeholders in Germany. They have important rights that are realized through labor councils at the company level. In large companies, employees' representatives may have up to half of the seats in the membership of the supervisory board. Also, employees in Japan are traditionally important stakeholders, who often devote whole career to the same company.

Besides Germany, other developed European countries also show a higher degree of social care and protection of its citizens in relation to the USA: longer vacations, better systems of employees sick leave, state pension funds, etc. Demographic and economic estimates, however, indicate that many social protection systems in continental Europe and Japan could in the future become insolvent. This applies in particular to the state pension funds on the ground that in the coming decades is expected significantly higher number of pensioners relative to the working population, which resulted in the popularization of investments in private pension funds, investment funds and securities. 


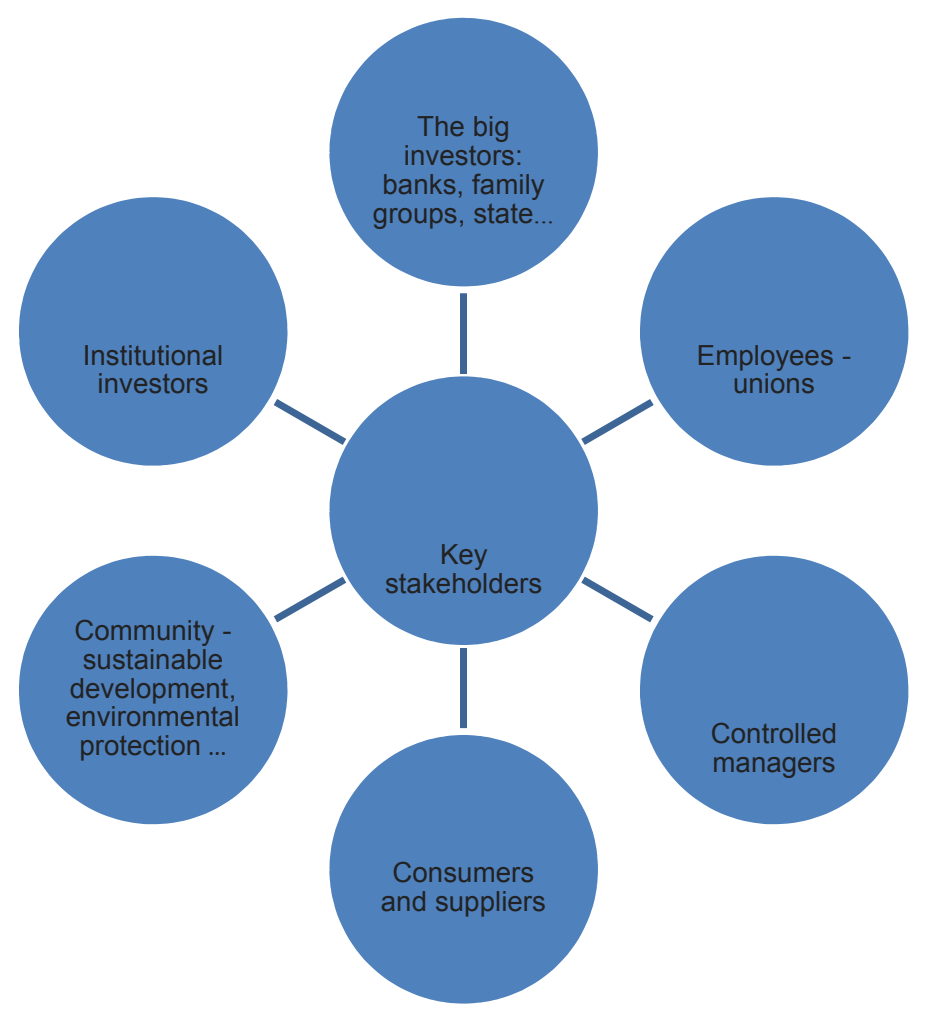

Figure 2. Key stakeholders in the continental system of value creation

Unlike traditional majority shareholders, the new group of minority shareholders are primarily interested in the growth of the share price and dividend payments, which imposes the need for significant appreciation of the Anglo-American concept of shareholder value creation. In this sense, the large German banks and insurance companies have begun to reduce its presence in the boards of corporations with the announcement that they will manage share portfolios more according to "shareholder value" principles. [Sigurt 2003: 6-7]

Also, an increasing number of corporations whose head office are located outside the Anglo-American countries, accept the shareholder value creation as an important business goal. The above-mentioned effects of the process of globalization, however, does not signify the transformation of stakeholder concept in the traditional concept of shareholder value. Institutional investors are included in a network of key stakeholders (Figure 2), and substantial changes occur only in the ownership structure. Finally, it can be concluded that the processes of globalization largely lead to the harmonization of Anglo-American and continental practice and general acceptance of long-term stakeholder value creation necessity.

\section{The Impact of the Economic Crisis on the Importance of Key Stakeholders}

In previous text, mainly were analyzed the experiences of developed countries in the years before the onset of the global economic crisis. The crisis has, however, created an entirely new economic conditions. In the current situation, as the main goal for a large number of corporation is imposed survival and waiting for better times.

The global economic crisis has significantly affected the balance of power between the key stakeholders in modern corporations. It is indisputable that the most serious consequences of the economic crisis is borne by the employees, because of recently unprecedented wave of layoffs. In conditions of limited revenues, dismissal of employees or the reduction of salaries is the first step in reducing total expenditures. Large supply and reduce demand on the labor market greatly weakens the "bargaining" power of employees. On the other hand, the decline in purchasing power and demand for products and services (and consequently a fall in prices), leads to the fact that customers are becoming more and more important stakeholders. The owners, in order to maintain their company, in the short term are often willing to hand over more "piece of pie" to customers or to do business on the verge of profitability (Figure 3). 


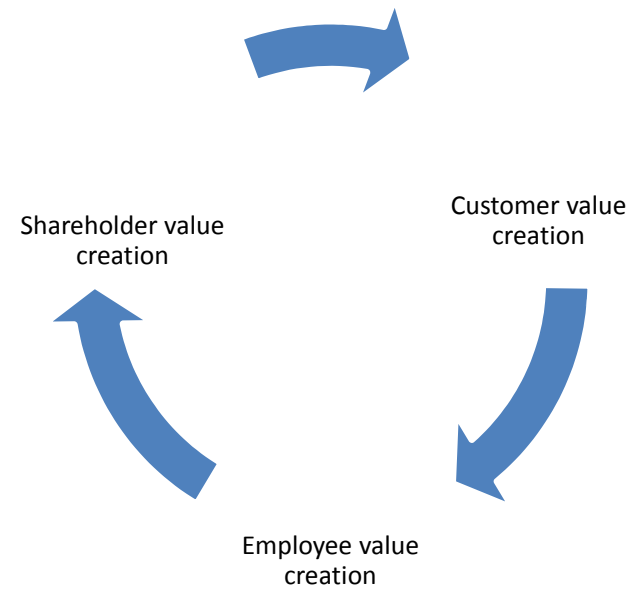

Figure 3. Value creation chain for key stakeholders

According to previous considerations, it can be concluded that the key stakeholders, in terms of value creation, are primarily the shareholders, customers and employees. Here could be placed question of the absence of some other very influential stakeholders, such as government or creditors. From the point of "opportunity yield", value for a particular group of stakeholders is generated when the group achieves greater benefit compared to the benefit that could be realized in similar companies.

In this sense, it is obvious that a company can not be set as a target value creation for the state, which would imply to pay higher taxes than required. Corporations, however, often set as a major goal of business support to the local community (donations to schools, hospitals, charitable organizations, etc.). In this way they promote and increase the business reputation of the company.

Banks can significantly affect the business activities of corporations, primarily in order to secure repayment of the loan (the requirement to maintain a certain level of liquidity, solvency, etc.). In relations with creditors, however, one can not speak of the need to create value for this group of stakeholders. Companies will usually not pay to creditors more than what was agreed or expected.

Changing of creditors importance in times of crisis can be viewed from two entirely different perspectives. On the one hand, in the current conditions of limited sources and general illiquidity, the survival of a large number of companies is directly associated with new loans and/or rescheduling of existing obligations. In other words, the impact of creditors has extremely increased. On the other hand, it can be noted that a significant number of successful corporations are trying to be, as much as possible, financed from its own resources. It can be expected that in the following years corporations will be much more careful when taking large loans and that the banking sector will set stricter lending conditions.

The global economic crises have significantly changed the role of the state. According to the basic concept of neoliberalism, developed countries regulate only the general terms of business and do not interfere directly in the business of an individual corporate enterprises, except in some special cases of national interests or necessity to ensure functioning of the free market, such as preventing the formation of cartels. The global economic crisis has, however, imposed the strengthening influence of the state. Unlike the 1980s, when some of the most developed European countries carried out the privatization of unprofitable state-owned enterprises (eg. sale of the British Telecom in 1984), during the economic crises opposite processes took place. The most developed countries during 2008 and 2009 invested huge funds in order to rescue the large banks and important corporations. As the result the state has become a major shareholder in these companies. It can be expected that after the crisis a certain decrease will occur in the share of state ownership, but it is certain that the state will remain one of the key stakeholders in corporations.

\section{Conclusion}

The former views on setting up one key goal of the corporation, such as maximizing the wealth of the owner, lose their importance in the contemporary world. Today, more and more talk are about pluralism of objectives, which are determined by the interests of many key stakeholders. Modern corporate enterprises should formulate a set of goals, which will be in a function of long-term value creation for the key stakeholders.

This statement, however, refers primarily to the developed countries, while in developing countries continue to dominate traditional concept of shareholder value creation. That implies significant neglect of the interests of other stakeholders. The majority owners, in the conditions of relatively closed markets, often do not want to give piece of the 
"pie" to customers, employees, suppliers or minority owners.

The worst consequences of the economic crisis felt the employees, while the decline in purchasing power and demand for products and services brought only a partial strengthening to the role of customers.

\section{Literature}

Foudy, J. J. (2003). Shareholder Value and the German and Japanese Models: A Case study of the Automobile Sector, Yale University.

Frankfurter, G., Wood, B., \& Wansley, J. (2003). Dividend Policy: Theory and Practice, Academic Press.

Harrison, J., \& Wicks, A. (2013). Stakeholder Theory, Value, and Firm Performance, Business Ethics Quarterly, 23(1), (January 2013), 97-124. https://doi.org/10.5840/beq20132314

Jovanović, A. (2002). Conference on the development of financial markets, December 9-10, the Federal Ministry of Finance, the Ministry of Finance and Economy of the Republic of Serbia, the Federal Commission for Securities and Financial Market, 33-47.

Rappaport, A., (2006). 10 Ways to Create Shareholder Value, Harvard Business Review, Reprint R0609C.

Sigurt, V. (2003). Verhandelter Shareholder Value: Die deutsche Variante einer angloamerikanischen Praxis, Discussion Paper SP II 2003 - 25, Wissenschaftszentrum Berlin.

\section{Copyrights}

Copyright for this article is retained by the author(s), with first publication rights granted to the journal.

This is an open-access article distributed under the terms and conditions of the Creative Commons Attribution license which permits unrestricted use, distribution, and reproduction in any medium, provided the original work is properly cited. 